\title{
Theoretical structural metabolomics
}

\section{J Apostolakis*, S Tietze, R Körner, J Marialke and S Berger}

Address: LMU, Munich, Institute for Informatics, Amalienstr. 17, D-80333 Munich, Germany

* Corresponding author

from 4th German Conference on Chemoinformatics

Goslar, Germany. 9-II November 2008

Published: 5 June 2009

Chemistry Central Journal 2009, 3(Suppl I):P60 doi:I0.II86/I752-I53X-3-SI-P60

This abstract is available from: http://www.journal.chemistrycentral.com/content/3/SI/P60

(C) 2009 Apostolakis et al; licensee BioMed Central Ltd.

The metabolome consists of all the low molecular weight molecules that are taken up, transformed and degraded by the cell. In many ways it represents the cells' interface with its chemical environment: It allows communication with the surroundings, and the gain of energy and building blocks. The metabolic state of the cell is mainly regulated by specific proteins, the enzymes, which catalyze the metabolic reactions, i.e. the transformation between different metabolites. Current developments in modelling may lead the way towards a cell wide analysis of the interaction between the proteome and the metabolome. This is the aim of theoretical structural metabolomics. In this talk I will outline a novel theoretical framework for analysing metabolic reactions and how they are catalysed by enzymes.

The framework is based on recent work for predicting the reaction centers of biochemical reactions (Koerner and Apostolakis 2008). On the basis of the predicted bond changes it is possible to derive constraints on the relative conformation of the substrates during the reaction. These constraints appear as pseudobonds, which allow treating the substrates of a reaction as a single molecule. That means that practically all methods from molecular modelling can be used for studying reactions. While the range of applications of this approach is extremely wide we will concentrate on the prediction of reactive enzyme-substrate complexes. To this end we use an adapted version of our GlamDock software (Tietze and Apostolakis, 2007). On a benchmark of more than 100 enzyme-substrate pairs we show that the accuracy of the prediction lies at around $45 \%$ (number of substrates predicted at rank 1
Munich, Germany

Fialke and S Berger

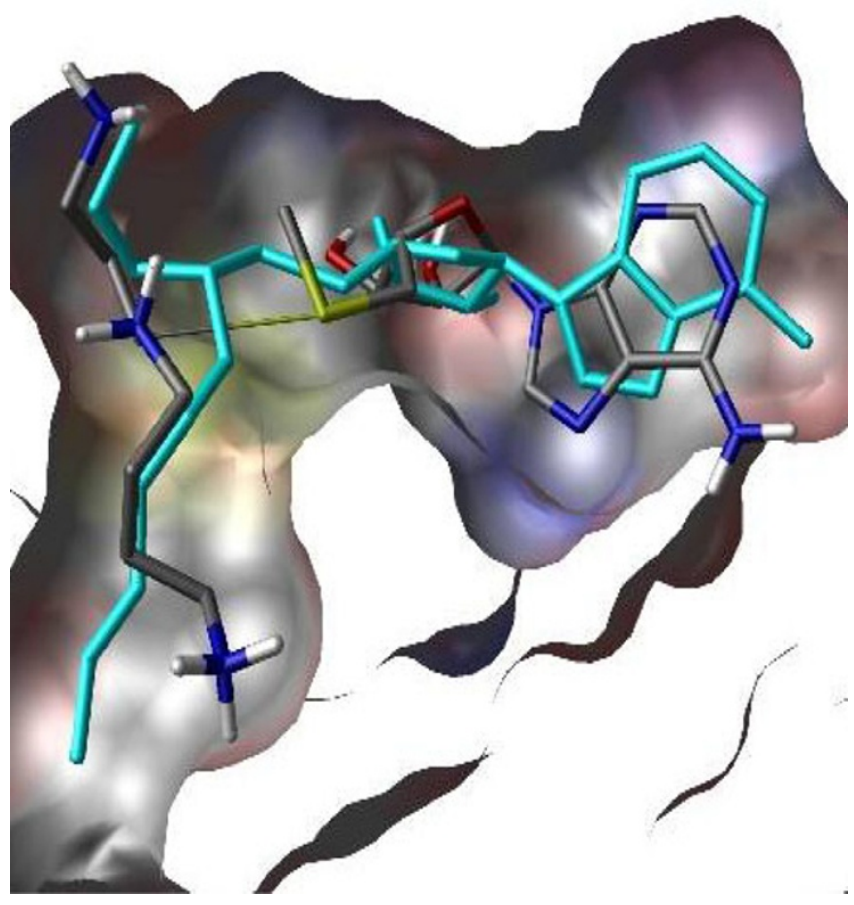

Munich, Germany

Prediction of the substrates of spermidine synthase in the active site of the enzyme (shown by the molecular surface). In light blue the structure of the transition state complex as seen in the crystal is shown, while the substrates of the reaction are shown in coloured stick. The pseudo bond is shown in a thin stick. 


\section{References}

I. Körner R, Apostolakis J: J Chem Inf Mod 2008, 48(6): I I8I- I I89.

2. Tietze S, Apostolakis J: J Chem Inf Mod 2007, 47(4):1657-1672.

\section{Publish with ChemistryCentral and every scientist can read your work free of charge}

"Open access provides opportunities to our colleagues in other parts of the globe, by allowing anyone to view the content free of charge."

$$
\text { W. Jeffery Hurst, The Hershey Company. }
$$

- available free of charge to the entire scientific community

- peer reviewed and published immediately upon acceptance

- cited in PubMed and archived on PubMed Central

- yours - you keep the copyright

Submit your manuscript here:

http://www.chemistrycentral.com/manuscript/

$(1$ Chemistry Centra 